\title{
Dual Security Fingerprint that is Utilizing as Well as in Bank System
}

\author{
S. Sangeetha, G.Kavitha, S. Amudha, G. Michael
}

\begin{abstract}
This paper defines utilising the ATM (Automatic Teller device) which supplies clients with all the banknote that is convenient are really typical. Nevertheless, the $f$ crime that is inancial increases over and over repeatedly in current $y$ ears; plenty of criminals tamper with all the ATM terminal and steal individual's charge card and password by unlawful means. When individual's charge card is lost as well as the password is taken, the criminal will draw all money in the shortest time, that may bring enormous losings which can be monetary consumer. How exactly to continue the legitimate identification towards the consumer becomes the main focus in present group that is economic. Old-fashioned ATM systems authenticate generally by making use of the credit card and the password, some defects are had by the technique. Making use of credit password and card cannot verify the client's identification. Generally there is absolutely essential to improve the protection that client make use of the ATM device. As soon as individual's charge card is lost and the password is taken, the criminal will draw all profit the shortest time, that may bring enormous losings which can be monetary consumer, therefore to rectify this dilemma we are applying in this work. The goal that is primary to help make the ATM device with additional safety by giving twin security in other words., fingerprint recognition and also by entering password. So, to conquer the issues which can be above are designing a work containing little finger printing audience, keypad which can be helpful for entering of password without needing ATM cards as wage do in the ATM's currently available. As soon as the nger that is fi etails are $g$ iven a window is exhibited regarding the $c$ ontroller, this contains keypad a nd $u$ sing that keypad we are able to enter the password after $b$ eing enrolled. Individual can enter the a mount to withdraw. And can get the note from note dispenser (stepper motor) interfaced with microcontroller.
\end{abstract}

KEYWORDS:Finger Print Reader, UART, ARM 7(LPC2129), Keypad, Steppermotor.

\section{INTRODUCTION}

Among most of the biometrics, fingerprint based recognition[1] is among the most mature and strategy that is proven. Cryptography offers the necessary tools for accomplishing protected and deals being authenticated. It not merely protects the information from alteration or theft, but in addition can be utilized for individual verification. An individual verification is control located in a regular

Revised Manuscript Received on July 22, 2019.

S. Sangeetha, Department ofCSE, Bharath Institute of Higher Education and Research,Chennai, Tamilnadu, India.

G.Kavitha, Department of CSE, Bharath Institute of Higher Education and Research,Chennai, Tamilnadu, India.

S. Amudha, Department of CSE, Bharath Institute of Higher Education and Research,Chennai, Tamilnadu, India.

G. Michael, Department of CSE, Bharath Institute of Higher Education and Research,Chennai, Tamilnadu, India. cryptographic system. The weakness of these verification [2] systems can it be can just only recognize the maker's belongings (cards) or exactly what he recalls (passwords, PINs etc.)

Automated biometric verification is an emerging industry to deal with this dilemma so it cannot ensure the identification regarding the manufacturer of a transaction. B y Fingerprint password and verification verification we are able to determine an individual with twin protection.This work developing a biometric verification scheme in ATM banking systems [3 ] supplying security that is twin. It primarily decreases the accessing time, whenever contrasted with manual based bank system. ATMs are actually a component that is normal of life so we carry ATM cards within our everyday life. There are many possibilities to reduce them or even to take the cards. By fingerprint recognition it gets to be more securable to users

and in addition bankers from theft and that can do deals which can be effortless. With the growth of biometric verification, incorporated biometrics and cryptosystems [4] has additionally been addressed. The pictures should be encrypted before sent for remote biometric verification. The permutation of pixels, the replacement of grey degree values, as well as the diffusion associated with the $m$ that is discredited can encrypt a picture effortlessly.

This work an embedded verification that is biometric is proposed. The fingerprint image obtained through the individual is encrypted within the ATM terminal for verification. The encrypted image $[5,6,7]$ is then sent on the secured channel to your banking terminal that is main. We $\mathrm{n}$ the banking terminal $\mathrm{f}$ ingerprint image is decrypted. The decrypted image is contrasted with the fingerprint templates. The verification is legitimate then we need to enter the best password to help make deals or even to enquire stability in the event that minutiae matching are effective plus. Then transaction becomes effective $[8,9,10]$.

\section{INSPIRATION}

The inspiration with this ongoing work is always to raise the protection thatconsumer utilize the ATM device. As soon as individual's charge card is lost while the password is taken, the criminal will draw all money i $\mathrm{n}$ enough time that is shortest, that will bring enormous monetary losings to consumer, therefore to rectify this issue we're applying this use double protection $[11,12,13]$.

The goal that is primary to really make the ATM device with additional protection by supplying double security in other words., fingerprint recognition and also by entering 
password. Therefore, to conquer the issues being above are designing a task containing hand printing audience, keypad that will be ideal for entering of password without the need for ATM cards once we do within the ATM's currently available. After the little finger details receive a window is shown regarding the controller, this contains using and keypad that keypad we are able to enter the password after being enrolled. Individual can enter the total amount to withdraw. And will get the note from note dispenser (stepper motor) $[14,15]$ interfaced with microcontroller.

Nowadays, utilising the ATM (Automatic Teller device) which supplies clients because of the banknote that is convenient is quite typical. Nevertheless, the criminal activity that is monetary increases over repeatedly in the past few years; lots of criminals tamper with all the ATM terminal and steal individual's bank card and password by unlawful means. When individual's charge card is lost therefore the password is taken, the criminal will draw all money $i \mathrm{n}$ enough time that is shortest, that will bring enormous monetary losings to consumer. How exactly to continue the legitimate identification to your consumer becomes the main focus in present group that is economic $[16,17]$.

\section{PROPOSED SYSTEM OVERVIEW}

In this block diagram contains a $\operatorname{ARM} 7[18,19,20]$ controller interfaced $\mathrm{w}$ ith hand printing audience, money keypad and dispenserand buzzer. Whenever an individual would like to draw the total amount from their cost savings he's got to provide their thumb impression regarding the fingerprint audience. $T$ he data read provided for microcontroller through com por $t$. When the information is browse the little finger details i s in contrast to the database. Then your individual is expected to enter the password if this fits. Then individual gets access to draw the specified quantity, if will not then there is absolutely no possibility for deals if this fits $[21,22,23]$.

Keypad is interfaced utilizing the microcontroller which waits for input from individual. Keypad interfaced could make the consumer to enter the password while the add up to be drawn. The total amount entered by individual is provided for microcontroller, executes operation that is matching provides the information i.e., add up to be dispensed to $\mathrm{n}$ ote dispenser (By stepper motor indicator).

Figure.1. Block Diagram of Dual security fingerprint that is making use of password in bank system

\section{EXPERIMENTAL OUTCOMES}

\section{Hardware Execution}

In this execution equipment such as for instance supply 7 controller that is microLPC 2129) [24], power, voltage Regulator, serial interaction (UART, RS232) [25] , fingerprint module, and money dispenser (Stepper motor) [26] iused. Computer software includes Keil IDE for ARM [27], secret f lash energy together with codes are written in Embedded C.When hand detected controller that is then micro submit the command to build little finger image. On s uccess little finger image controller that is micro cmd to come up with char file. On s uccess of char File generation micro controller will be sending search cmd that is quick. Module will search into the flash collection. If hand image can there be, it shall provide the access .It will show the ID quantity on LCD. Otherwise it shall show on lcd Finger not found. On effective access keypad w be enabled sick [28].

On key press controller that is micro submit cmd to have brand new Page ID (flash mem). Then Micro controller will be sending the demand to build hand image .On success finger image a controller that is micro cmd to create char file on $\mathrm{c}$ har buff1. Then once again micro controller the submit the command to create hand image. On success finger image micro controller gives cmd to build char file on char buff2. Then controller that is micro s end cmd to merge both a char fileto generate MATCH file controller that is.Then micro send cmd to keep create the MATCH file within the CHAR BUFFER.Power on controller, press key.Now buffer is emptied.Reset the controller [29].

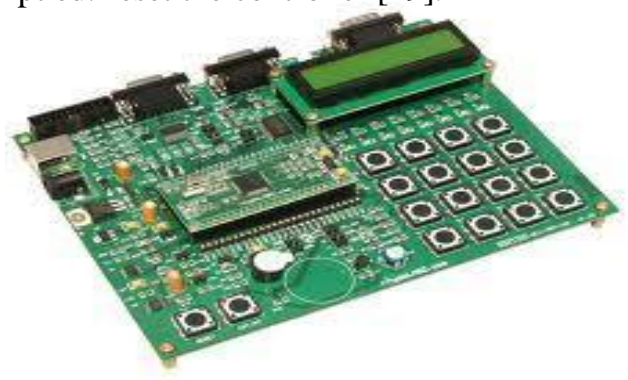

Figure 2. A RM 7 controller

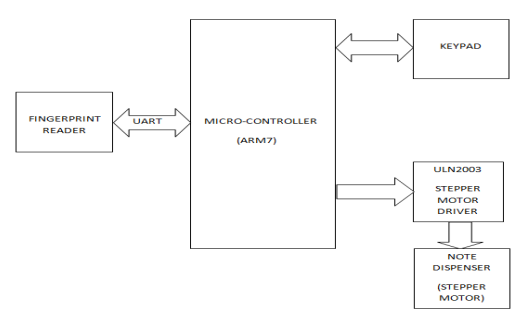




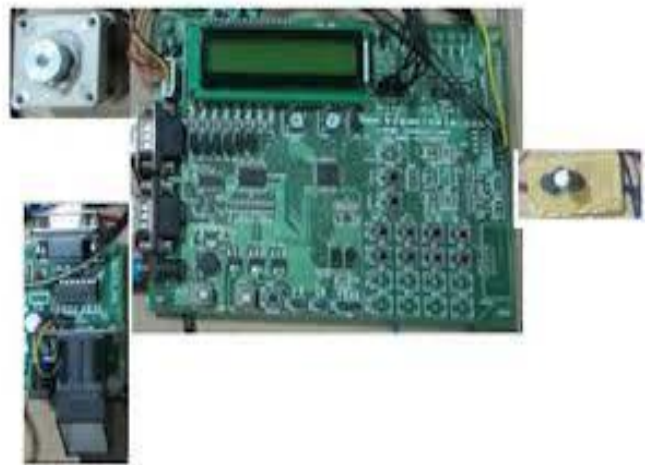

Figure. 3. Dual security fingerprint \&password kit

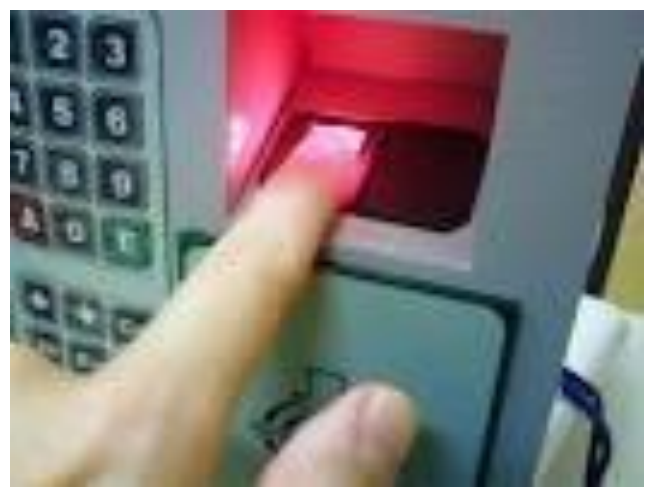

Figure 4. Place on hand

Businesses have actually recognized that hand printing scanning is an age ffective means of security today. While the price of applying scanners being biometric bigger businesses and information centers continues to be quite expensive [30].

\section{CONCLUSIONS AND FUTURE SCOPE}

In this work, is a safety that is double based onFingerprint password and recognition for the true purpose of banking by which fingerprint is $g$ enerated simply by using fingerprint audience associated with the thumb a nd the qualifications associated with the client. This information is stored in database. Authentication is shown by matching the rule of every entry that is matching of impression taken during the time of deal with compared to rule as well as the password saved in database. Key display and pad can be used to enter the password also to connect to individual and ATM for monetary deal. After the verification and information entered are effective, microcontroller make a plan in dispensing money from money dispenser to fit the total amount entered by individual [31, 32, 33].

This proposed system works for all applications being practical are employed in economic deals for verification of individual identification and avoidance from ATM card fraudulence. Double safety centered on password and fingerprint in banking in other words., t ATM devices may be improved in future [35, 36, 37].

Future range:

This work can be upgraded from FINGER PRINT sensors to FACE RECOGNITION sensor. Is upgraded to $\mathrm{k}$ eypad with touchscreen display.

\section{REFERENCES}

1. Kumarave A., Rangarajan K.,Algorithm for automaton specification for exploring dynamic labyrinths,Indian Journal of Science and Technology,V-6,I-SUPPL5,PP-4554-4559,Y-2013

2. P. Kavitha, S. Prabakaran "A Novel Hybrid Segmentation Method with Particle Swarm Optimization and Fuzzy C-Mean Based On Partitioning the Image for Detecting Lung Cancer" International Journal of Engineering and Advanced Technology (IJEAT) ISSN: 2249-8958, Volume-8 Issue-5, June 2019

3. Kumaravel A., Meetei O.N.,An application of non-uniform cellular automata for efficient cryptography,2013 IEEE Conference on Information and Communication Technologies, ICT 2013,V-,I-,PP-1200-1205,Y-2013

4. Kumarave A., Rangarajan K.,Routing alogrithm over semi-regular tessellations,2013 IEEE Conference on Information and Communication Technologies, ICT 2013,V-,I-,PP-1180-1184,Y-2013

5. P. Kavitha, S. Prabakaran "Designing a Feature Vector for Statistical Texture Analysis of Brain Tumor" International Journal of Engineering and Advanced Technology (IJEAT) ISSN: 2249-8958, Volume-8 Issue-5, June 2019

6. Dutta P., Kumaravel A.,A novel approach to trust based identification of leaders in social networks, Indian Journal of Science and Technology,V-9,I-10,PP--,Y-2016

7. Kumaravel A., Dutta P.,Application of Pca for context selection for collaborative filtering,Middle - East Journal of Scientific Research,V-20,I-1,PP-88-93,Y-2014

8. Kumaravel A., Rangarajan K.,Constructing an automaton for exploring dynamic labyrinths,2012 International Conference on Radar, Communication and Computing, ICRCC 2012,V-,I-,PP-161-165,Y-2012

9. P. Kavitha, S. Prabakaran "Adaptive Bilateral Filter for Multi-Resolution in Brain Tumor Recognition" International Journal of Innovative Technology and Exploring Engineering (IJITEE) ISSN: 2278-3075, Volume-8 Issue-8 June, 2019

10. Kumaravel A.,Comparison of two multi-classification approaches for detecting network attacks, World Applied Sciences Journal,V-27,I-11,PP-1461-1465,Y-2013

11. Tariq J., Kumaravel A.,Construction of cellular automata over hexagonal and triangular tessellations for path planning of multi-robots,2016 IEEE International Conference on Computational Intelligence and Computing Research, ICCIC 2016,V-,I-,PP--,Y-2017

12. Sudha M., Kumaravel A.,Analysis and measurement of wave guides using poisson method,Indonesian Journal of Electrical Engineering and Computer Science,V-8,I-2,PP-546-548,Y-2017

13. Ayyappan G., Nalini C., Kumaravel A., Various approaches of knowledge transfer in academic social network, International Journal of Engineering and Technology,V-,I-,PP-2791-2794,Y-2017

14. Kaliyamurthie, K.P., Sivaraman, K., Ramesh, S. Imposing patient data privacy in wireless medical sensor networks through homomorphic cryptosystems 2016, Journal of Chemical and Pharmaceutical Sciences 92.

15. Kaliyamurthie, K.P., Balasubramanian, P.C. An approach to multi secure to historical malformed documents using integer ripple transfiguration 2016 Journal of Chemical and Pharmaceutical Sciences 92 .

16. A.Sangeetha,C.Nalini,"Semantic Ranking based on keywords extractions in the web", International Journal of Engineering \& Technology, 7 (2.6) (2018) 290-292

17. S.V.GayathiriDevi,C.Nalini,N.Kumar,"An efficient software verification using multi-layered software verification tool "International Journal of Engineering \& Technology, 7(2.21)2018 454-457

18. C.Nalini,ShwtambariKharabe,"A Comparative Study On Different Techniques Used For Finger - Vein Authentication", International Journal Of Pure And Applied Mathematics, Volume 116 No. 82017 , 327-333, Issn: 1314-3395

19. M.S. Vivekanandan and Dr. C. Rajabhushanam, "Enabling 
Privacy Protection and Content Assurance in Geo-Social Networks", International Journal of Innovative Research in Management, Engineering and Technology, Vol 3, Issue 4, pp. 49-55, April 2018.

20. Dr. C. Rajabhushanam, V. Karthik, and G. Vivek, "Elasticity in Cloud Computing", International Journal of Innovative Research in Management, Engineering and Technology, Vol 3, Issue 4, pp. 104-111, April 2018

21. K. Rangaswamy and Dr. C. Rajabhushanamc, "CCN-Based Congestion Control Mechanism In Dynamic Networks", International Journal of Innovative Research in Management, Engineering and Technology, Vol 3, Issue 4, pp. 117-119, April 2018.

22. Kavitha, R., Nedunchelian, R., "Domain-specific Search engine optimization using healthcare ontology and a neural network backpropagation approach", 2017, Research Journal of Biotechnology, Special Issue 2:157-166

23. Kavitha, G., Kavitha, R., "An analysis to improve throughput of high-power hubs in mobile ad hoc network" , 2016, Journal of Chemical and Pharmaceutical Sciences, Vol-9, Issue-2: 361-363

24. Kavitha, G., Kavitha, R., "Dipping interference to supplement throughput in MANET" , 2016, Journal of Chemical and Pharmaceutical Sciences, Vol-9, Issue-2: 357-360

25. Michael, G., Chandrasekar, A.,'Leader election based malicious detection and response system in MANET using mechanism design approach", Journal of Chemical and Pharmaceutical Sciences(JCPS) Volume 9 Issue 2, April - June 2016.

26. Michael, G., Chandrasekar, A.,"Modeling of detection of camouflaging worm using epidemic dynamic model and power spectral density", Journal of Chemical and Pharmaceutical Sciences(JCPS) Volume 9 Issue 2, April - June 2016.

27. Pothumani, S., Sriram, M., Sridhar, J., Arul Selvan, G., Secure mobile agents communication on intranet,Journal of Chemical and Pharmaceutical Sciences, volume 9, Issue 3, Pg No S32-S35, 2016

28. Pothumani, S., Sriram, M., Sridhar, Various schemes for database encryption-a survey, Journal of Chemical and Pharmaceutical Sciences, volume 9, Issue 3, Pg NoS103-S106, 2016

29. Pothumani, S., Sriram, M., Sridhar, A novel economic framework for cloud and grid computing, Journal of Chemical and Pharmaceutical Sciences, volume 9, Issue 3, Pg No S29-S31, 2016

30. Priya, N., Sridhar, J., Sriram, M. "Ecommerce Transaction Security Challenges and Prevention Methods- New Approach” 2016 ,Journal of Chemical and Pharmaceutical Sciences, JCPS Volume 9 Issue 3.page no:S66-S68

31. Priya, N.,Sridhar,J.,Sriram, M.“Vehicular cloud computing security issues and solutions" Journal of Chemical and Pharmaceutical Sciences(JCPS) Volume 9 Issue 2, April - June 2016.

32. Priya, N., Sridhar, J., Sriram, M. "Mobile large data storage security in cloud computing environment-a new approach" JCPS Volume 9 Issue 2. April - June 2016

33. Anuradha.C, Khanna.V, "Improving network performance and security in WSN using decentralized hypothesis testing "Journal of Chemical and Pharmaceutical Sciences(JCPS) Volume 9 Issue 2, April - June 2016

34. Anuradha.C, Khanna.V, "A novel gsm based control for e-devices" Journal of Chemical and Pharmaceutical Sciences(JCPS) Volume 9 Issue 2, April - June 2016

35. Anuradha.C, Khanna.V, "Secured privacy preserving sharing and data integration in mobile web environments " Journal of Chemical and Pharmaceutical Sciences(JCPS) Volume 9 Issue 2, April - June 2016.

36. Sundarraj, B., Kaliyamurthie, K.P. Social network analysis for decisive the ultimate classification from the ensemble to boost accuracy rates 2016 International Journal of Pharmacy and Technology 8

37. Sundarraj, B., Kaliyamurthie, K.P. A content-based spam filtering approach victimisation artificial neural networks 2016 International Journal of Pharmacy and Technology $8 \quad 3$.

38. Sundarraj, B., Kaliyamurthie, K.P. Remote sensing imaging for satellite image segmentation 2016 International Journal of Pharmacy and Technology $8 \quad 3$.

39. Sivaraman, K., Senthil, M. Intuitive driver proxy control using artificial intelligence 2016 International Journal of Pharmacy and Technology $8 \quad 4$.

40. Sivaraman, K., Kaliyamurthie, K.P. Cloud computing in mobile technology 2016 Journal of Chemical and Pharmaceutical Sciences 92.
41. Sivaraman, K., Khanna, V. Implementation of an extension for browser to detect vulnerable elements on web pages and avoid click jacking 2016 Journal of Chemical and Pharmaceutical Sciences 9 2 .

\section{AUTHORS PROFILE}

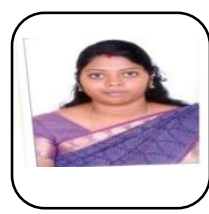

S. Sangeetha, Assistant Professor, Department of Computer Science and Engineering, Bharath Institute of Higher Education and Research, Chennai, India.

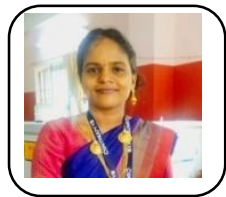

G. Kavitha, Assistant Professor, Department of Computer Science and Engineering, Bharath Institute of Higher Education and Research, Chennai, India.

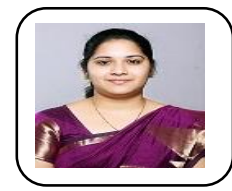

S. Amudha, Assistant Professor, Department of Computer Science and Engineering, Bharath Institute of Higher Education and Research, Chennai, India.

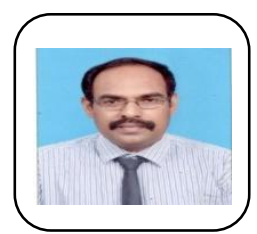

Dr. G.Michael, Associate Professor, Department of Computer Science and Engineering, Bharath Institute of Higher Education and Research, Chennai, India. 